\title{
Identifying global priorities for the conservation of vipers
}

Bryan Maritz, Johannes Penner, MarcioMartins, Jelka Crnobrnja-Isailović, Stephen Spear, Laura R.V. Alencar, Jesús Sigala-Rodriguez, Kevin Messenger, Rulon W. Clark, Pritpal Soorae, Luca Luiselli, Chris Jenkins and HarryW. Greene

\begin{abstract}
Vipers are among the most misunderstood and persecuted animals. They occupy most terrestrial ecosystems around the world, often at high population densities. However, certain aspects of their biology (e.g., low fecundity and slow growth) have resulted in vipers being disproportionately threatened by extinction. Despite increased extinction risk, relatively little is known about viper biology, severely limiting the development and implementation of conservation initiatives. Here, we review the conservation status of vipers globally, map species richness, and develop three indices (one reactive; one proactive; one combined index emphasising irreplaceable species facing severe threats) to identify species for which conservation action should be prioritised. Moreover, we map species richness weighted by each index to identify regions for conservation prioritisation. We ranked prioritisation scores for all species for which data were available. In doing so we identify species for which valuable data are missing and that should be prioritised for research. We additionally show that 17 species, currently listed as Not Assessed or Data Deficient by the IUCN, score sufficiently high on our Threat Index to be considered as Threatened in the future. We identify multiple regions for which viper conservation action should be prioritised. These areas broadly correlate with species richness patterns, suggesting that species richness may be an effective proxy for conservation planning. Finally, we discuss the major gaps in knowledge, as well as the major threats facing vipers.
\end{abstract}

\section{Introduction}

Snakes are among the most misunderstood and persecuted groups of all animals (Dodd, 1987; Greene and Campbell, 1992; Beaupre and Duvall, 1998). The widely-held negative perceptions of snakes, coupled with relatively poor understanding of even their basic biology, pose fundamental challenges to snake conservation (Burghardt et al., 2009). These challenges are particularly apparent in the case of vipers (Family Viperidae, 330 species), a clade of advanced snakes that inhabit all continents except Australia and Antarctica, and are found in nearly all terrestrial ecosystems, from deserts to moist tropical forests (e.g., Mallow et al., 2003; Campbell and Lamar, 2004; Gumprecht et al., 2004). Vipers are characterized by advanced venom delivery mechanisms (Young et al., 2001; Cundall, 2002) 
and highly complex, potent natural toxins (Norris, 2004), such that they are an important contributor to the global public health problem of venomous snakebite (e.g., Chippaux, 1998; Gutiérrez et al., 2010).

Vipers are characterized by phylogenetically widespread viviparity and parental care (Fenwick et al., 2011; Greene et al., 2002), ambush foraging (Cundall and Greene, 2000) for prey as diverse as centipedes, insects, fish, amphibians, reptiles, birds, and mammals (Greene, 1997; Martins et al., 2002), and relatively low metabolic rates and energy requirements (Nowak et al., 2008). These traits have contributed to vipers reaching the highest latitudes (over $65^{\circ}$ North in Vipera berus and $47^{\circ}$ South in Bothrops ammodytoides) and elevations (up to $4800 \mathrm{~m}$ above sea level in Gloydius himalayanus in Nepal or up to $4570 \mathrm{~m}$ a.s.l. in Crotalus triseriatus in Mexico) of any snake species. However, several of these traits associated with "slow" life-histories (e.g., ambush foraging resulting in infrequent feeding on large prey; Greene, 1983) may also make vipers particularly vulnerable to extinction (Greene and Campbell, 1992; Reed and Shine, 2002). Accordingly, Böhm et al. (2013) found that vipers were significantly more threatened than expected in an analysis of 1500 randomly selected reptile species. Indeed, although vipers represent only $9 \%$ of all snakes (Uetz and Hošek, 2015), they currently comprise $20 \%$ of the 226 snakes listed as threatened on the IUCN Red List (IUCN, 2015a). Globally, 20 species of vipers are listed as Vulnerable, 23 as Endangered, and eleven as Critically Endangered (IUCN, 2015a; M. Martins et al. unpublished data).

Conservation prioritisation offers a useful tool to direct limited resources toward actions that return the greatest conservation impacts relative to a priori objectives (Myers, 1988; Myers et al., 2000). These conservation objectives produce prioritisation plans that are proactive (emphasising irreplaceability of biodiversity) or reactive (emphasising vulnerability of biodiversity; Brooks et al., 2006). While reactive indices tend to map similar threat processes (human population, habitat transformation and fragmentation etc.), proactive indices vary widely in metrics used, from endemic species richness (Myers et al., 2000) to evolutionary distinctiveness (May, 1990; Isaac et al., 2007) and functional diversity (Petchey and Gaston, 2006). Moreover, proactive indices are often produced based on the geographic patterns of relatively well-known indicator taxa (Böhm et al., 2013), despite variable congruence of such patterns among different taxa (Grenyer et al., 2006). Thus, taxon-specific conservation priorities may be overlooked by some global prioritisation procedures (e.g. compare to Meiri and Chapple, in this issue), stifling access to conservation resources, especially when those taxonomic groups are poorly known.

Here, we review the conservation status of vipers globally, map viper species richness, and develop three indices to identify species for which conservation action should be prioritised. These indices differ in being reactive (dependent on threat processes) and proactive (dependent on ecological and evolutionary distinctiveness) (Brooks et al., 2006), with the third index producing a combined metric that emphasises irreplaceable species facing severe 
threats (Isaac et al., 2007). We additionally map viper species richness weighted by each of the prioritisation indices to identify regions of conservation priority. In doing so we identify gaps in our knowledge that currently hinder conservation planning for these animals. Finally, we provide a discussion of the status quo of viper conservation and the major threats facing vipers, as well as recommendations for viper conservation that we hope will form the basis of the proposed Viper Action Plan (VAP).

\section{Methods}

We gathered data regarding geographic distributions for 329 species of vipers recognised in the Reptile Database (after Uetz and Hošek, 2015, see Supplementary Material) by digitising polygon maps from field guides and taxonomic revisions. We additionally gathered information regarding life-history traits (body size, fecundity, diet) and evolutionary distinctiveness (see Section 2.2) for as many species as possible. Using these data we developed two separate prioritisation indices: a Threat Index (TI) that uses selected species traits and anthropogenic impacts within the geographic distribution of each species as measures of current threats to the persistence of the species; and an index of Ecological and Evolutionary Distinctiveness (EED) that uses selected species traits to prioritise species that represent distinct evolutionary lineages or extremes of ecological traits. We additionally calculated a third index, based on the conceptual approach of the EDGE index (Isaac et al., 2007) that aims to prioritise evolutionarily distinct (ED) and Globally Endangered (GE) species by averaging our measures of TI and EED for each species to identify ecologically and evolutionarily distinct species that are highly threatened. We mapped our conservation priority indices by summing the index scores of all species present in a particular grid cell, resulting in prioritisation-index-weighted species richness maps (Fig. 1B/D/F/G). Finally, we identify hotspots by mapping the highest scoring $10 \%$ of cells globally for each index.

\subsection{Threat Index (TI)}

We calculated the size of the geographic distribution (GD, area of the geographic distribution polygon) of each species, the degree of human impact (HI; from the HII of the Global Human Influence Index (WCS and CIESIN, 2005)) within that distribution, and the percentage of each distribution formally protected (PA; IUCN protected area category I-IV from the World Database of Protected Areas (IUCN and UNEP-WCMC, 2015), plus Biosphere Reserve protected areas in Mexico and National Parks in South Africa for which IUCN categories are not reported in the WDPA). We additionally used expert opinion, facilitated through IUCN Viper Specialist Group (URL: http://www.oriannesociety.org/iucn-viper-specialist-group) regional coordinators, to estimate the ability of each species to persist in altered habitats (AAH: after Filippi and Luiselli, 2000, in categories ranging from 1 (high persistence) to 4 (low persistence)).

We rationalised that species with small, highly transformed and poorly protected geographic distributions, that were perceived to have a limited capacity to persist in altered habitats were likely to be most threatened and used this hypothesis to dictate the rank ordering of species. We 
normalized each variable to range between 0 and 1 , including only species for which data were available. Autocorrelation among variables was low (max: $\mathrm{r}=0.44$ ) so no variables were excluded from the calculation of the index. We excluded species for which fewer than three variables were available, and calculated the threat index as the mean of the available variables. Our TI is based on the same rationale as the IUCN Red List in that it evaluates species on the basis of their vulnerability to current threats. However, there is only partial overlap between our TI parameters and the Red List criteria. As a result, comparison of TI values and IUCN Red List categorisations can provide insight into both the complementarity of different reactive indices and highlight species of conservation concern that may be overlooked. We thus compared our TI measures to derived Red List index scores for species with existing IUCN Red List assessments (IUCN, 2015a; M. Martins et al. unpublished data) using correlational analysis. We allocated each listed species a score based on the hierarchy of the Red List categories $(\mathrm{LC}=0 ; \mathrm{NT}=1 ; \mathrm{VU}=2 ; \mathrm{EN}=3 ; \mathrm{CR}=4)$. We excluded species listed as Data Deficient because of the ambiguity of this categorisation (Morais et al., 2013).

\subsection{Ecological and Evolutionary Distinctiveness (EED)}

We estimated an index of Ecological and Evolutionary Distinctiveness (modified from Gaiarsa et al., 2015) for each species for which data were available. We collected information regarding maximum reported total length of the largest sex (hereafter: length), maximum reported litter or clutch size (hereafter: litter/clutch size), and the number of prey classes (prey classes: invertebrates; fish; amphibians; reptiles; birds; mammals) known from the diet of that species. Ecological variables included body size (BS; calculated as the absolute difference between the log-transformed length for a given species from the mean log-transformed length for all species), maximum fecundity (MF, calculated as the absolute difference between the log-transformed litter/clutch size for a given species from the mean log-transformed litter/clutch size for all species), dietary specialisation (DS, inverse of the number of prey classes reported in the literature as prey of each species), habitat breadth (HB; defined as the number of WWF ecoregions (Olson et al., 2001) overlapped with the geographic distribution of each species), and elevational range (EL, range of elevations covered by geographic distribution). Correlation analysis revealed that elevational range and habitat breadth were strongly positively correlated $(\mathrm{r}=0.65)$. We thus excluded habitat breadth (which showed higher correlation coefficients with other variables than did elevational range). We used the most recent and complete molecular phylogenetic dataset of vipers (Alencar et al., in review) to calculate the evolutionary distinctiveness (ED) scores for each species. We estimated ED for vipers by applying the widely used ED fair proportion scoring method (Isaac et al., 2007). The ED score for a given species in the phylogeny is given by the sum of the ED scores estimated for the branch lengths from the root to the species. The ED score of each branch is calculated by dividing the branch length (given in millions of years) by the number of species descending from that branch (see Isaac et al., 2007). We calculated the ED score for each species using the maximum credibility tree generated by Alencar et al. (in review). We performed the ED estimates using the ed.calc function from the R package caper (Orme et al., 2013; R Core Team, 2015). Because the phylogeny comprises 264 out of 331 currently described species of 
vipers (Uetz and Hošek, 2015, the VSG currently recognising 329 valid species), we estimated the ED scores for the missing species as the mean of the ED scores of congeneric species present in the phylogeny (Collen et al., 2011; Curnick et al., 2015), except in a few cases (see below). Since the position of missing species may vary from a basal position to a more recent one in the lineage, we also provide the range of EDs for each species to represent this uncertainty (see Supplementary Material); to calculate the ED for the most basal position, we created a divergence event in the midpoint of the ancestral branch of the lineage, and to represent a more recent position we did the same with the ancestral branch of the species bearing the lowest ED score in the lineage. The ED score for the monotypic Montatheris hindii was given as the mean of the ED scores of the subfamily Viperinae (following suggestions in Curnick et al., 2015). Missing species belonging to the genera Bothrops and Bothrocophias had their ED scores assigned as the mean of the ED scores estimated for Bothrops + Bothrocophias. We chose to use this procedure because although the monophyly of both genera is not well supported, a clade comprising Bothrops and Bothrocophias is highly supported (Alencar et al., in review; Pyron et al., 2013). Missing Ovophis and Trimeresurus species had their ED scores assigned as the mean of their respective genera excluding Ovophis okinavensis and Trimeresurus gracilis respectively as both species have been shown to form a distinct clade unrelated to Ovophis or Trimeresurus (Pyron et al., 2013; Alencar et al., in review).

As with the TI measures, we ranked all species for which data were available $(\mathrm{N}=246)$ and normalized each variable to between $\mathrm{o}$ and 1 . We excluded species for which fewer than 4 variables were available $(\mathrm{N}=83)$, and calculated $\mathrm{EED}$ as the mean of the available variables.

\subsection{Combined Index (TI \& EED)}

Our TI and EED indices were not correlated $(\mathrm{r}=0.25)$. We therefore averaged the two indices to identify species that exhibit exceptional traits and face significant threat within their ranges. 

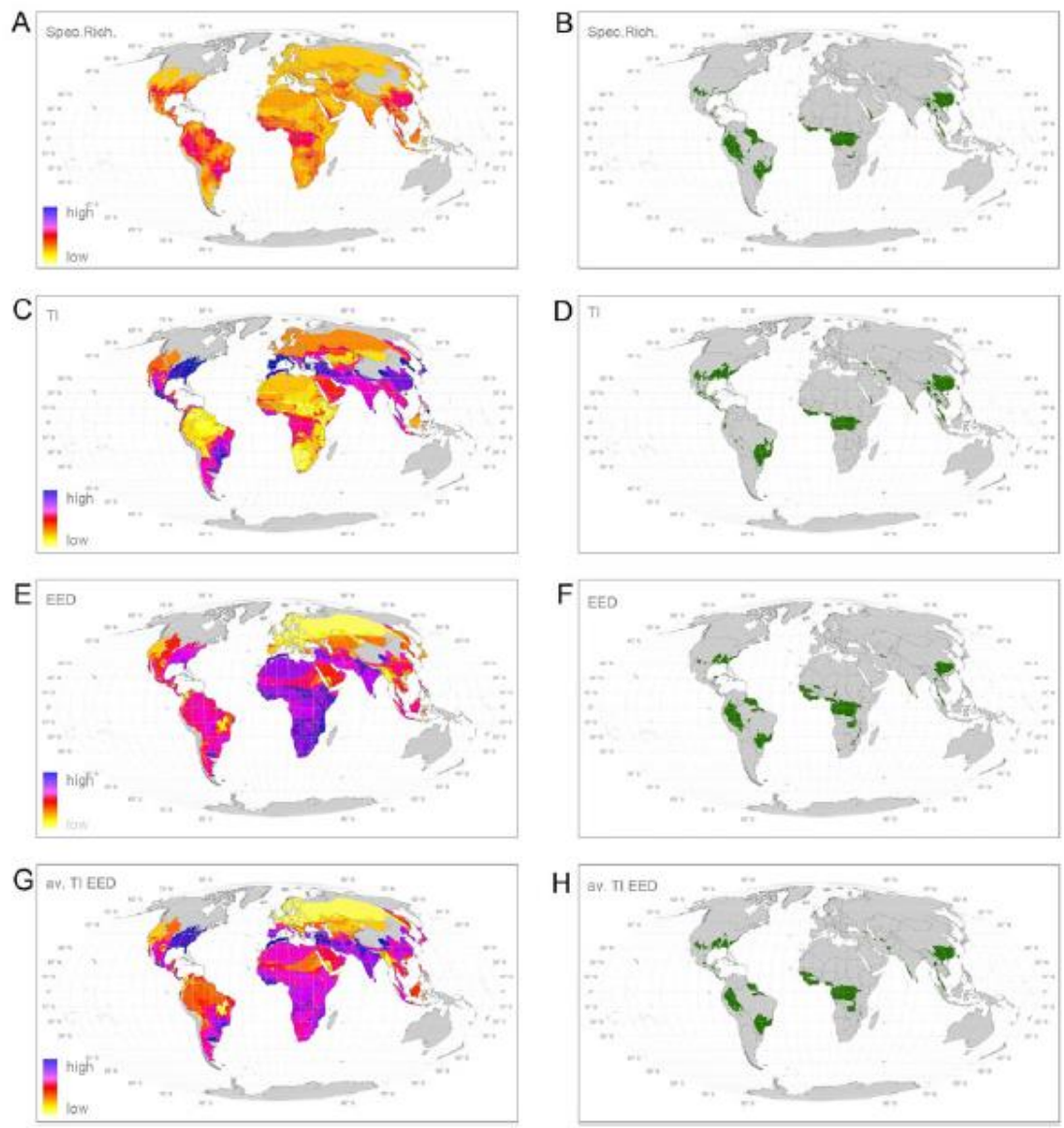

Fig. 1. Species richness (A) and top $10 \%$ species-rich grid cells (B) for vipers globally, followed by species richness weighted by Threat Index (TI; C) and showing highest $10 \%$ hotspots (D), species richness weighted by index of Ecological and Evolutionary Distinctiveness (EED; E) and highest 10\% hotspots (F), and species richness weighted by combined TI and EED indices (G) and highest $10 \%$ hotspots $(\mathrm{H})$.

\section{Results}

Species richness of vipers (Fig. 1A) ranged from 1 to 10 species per

cell (mode $=3$ species). Regions of highest species richness (Fig. 1B) were detected across the southern USA, as isolated nodes throughout Mesoamerica, as three large nodes in South America, across West and Central Africa, along the western edges of the Arabian peninsula and India respectively, north-eastern Iran and adjacent Afghanistan, and throughout southeast Asia (particularly south-eastern China). However, cells with high species richness were relatively rare with grid cells containing 8-10 species accounting for fewer than $1 \%$ of all cells containing vipers.

We gathered sufficient data to assign TI scores to 320 species (97\% of species; Table 1 ; Supplementary Material), with the majority of missing species being island endemics of the genus Crotalus. Despite excluding many island endemic Crotalus, the Top 30 TI species in our analysis disproportionately (relative to overall species richness) represented island endemics $\left(X^{2}=4.16 ; P=0.04\right)$. TI-weighted species richness (Fig. $1 \mathrm{C}$ ) was unsurprisingly correlated with overall species richness $(\mathrm{r}=0.9)$, but the regions with the highest TI-weighted scores (Fig. 
1D) additionally highlighted the south-eastern USA, large portions of Mesoamerica, several nodes in the Middle-east, western India and large portions of the greater Malaysian peninsula.

TI was significantly positively correlated with Red List scores for assessed species $(\mathrm{r}=0.58$; $\mathrm{P} \mathrm{b}$ 0.001). Moreover, we detected significant differences in mean TI for species in each IUCN group $\left(\mathrm{F}_{1,220}=95.18 ; \mathrm{P}\right.$ b 0.001; Fig. 2$)$, and pairwise comparisons between groups revealed significant differences $(\mathrm{P} \geq 0.05)$ for all comparisons except Vulnerable and Endangered $(\mathrm{P}=$ o.86). Importantly, TI 95\% confidence limits for Least Concern species ranged up to 0.74, providing a valuable threshold for highlighting potentially threatened species that have yet to be formally assessed by the IUCN or that are currently listed as Data Deficient. We found that 17 Not Assessed or Data Deficient species (Cerastes boehmei, Cerrophidion petlalcalensis, Crotalus ericsmithi, Crotalus lannomi, Crotalus tancitarensis, Echis megalocephalus, Gloydius lijianlii, Gloydius liupanensis, Gloydius monticola, Montatheris hindii, Porthidium hespere, Porthidium volcanicum, Protobothrops dabieshanensis, Protobothrops maolanensis, Trimeresurus fasciatus, Trimeresurus mcgregori, and Trimeresurus sichuanensis) had TI scores in excess of 0.75 and are likely to be considered Threatened in the future. These include 11 species currently listed as Data Deficient (48\% of all DD viper species).

Ecological and Evolutionary Distinctiveness (EED) was calculated for 246 species $(75 \%$ of species; Table 1; Supplementary Material). The Top 30 EED species disproportionately represented African species $\left(\chi^{2}=5.41 ; P=0.02\right)$, with ten sub-Saharan and two North African species making the Top 30 list, despite African vipers only accounting for approximately $20 \%$ of all species. Moreover, we lacked sufficient data to assess $33 \%$ of African species, suggesting that this effect is likely underestimated. Overall EED-weighted species richness (Fig. 1E) was strongly correlated with overall species richness $(r=0.93)$ but emphasised the South American, African, middle-eastern, and south Asian viper faunas. As a result, regions with highest EED-weighted species richness (Fig. 1B/F) were similar to overall species richness and highlighted most of the major priority nodes identified using species richness alone. 


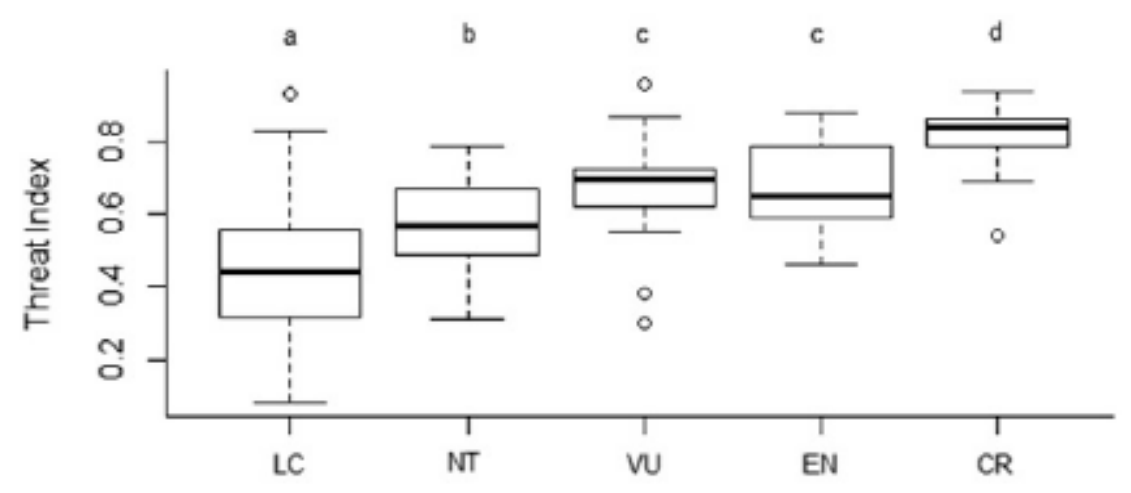

Red List Category score

Fig. 2. Mean Threat Index (TI) scores for IUCN Red List assessed vipers in each Red List category.

\begin{tabular}{|c|c|c|c|}
\hline Rank & Threat Index (TI) & Ecological \& Evolutionary Distinctiveness (EED) & Combined (TI \& EED) \\
\hline 1 & Crotalus unicolor & Protobothrops himalayanus & Montatheris hindii \\
\hline 2 & Trimeresurus sichuanensis & Montatheris hindii & Crotalus transversus \\
\hline 3 & Gloydius shedaoensis & Hypnale zara & Bothrops lanceolatus \\
\hline 4 & Bitis albanica & Bitis rhinoceros & Protobothrops mangshanensis \\
\hline 5 & Crotalus transversus & Protobothrops mangshanensis & Bothrops alcatraz \\
\hline 6 & Crotalus tancitarensis & Bothrops lanceolatus & Gloydius shedaoensis \\
\hline 7 & Bothrops lojanus & Hypnale nepa & Mixcoathus barbouri \\
\hline 8 & Montivipera albizona & Bitis peringueyi & Trimeresurus fasciatus \\
\hline 9 & Trimeresurus honsonensis & Azemiops feae & Hypnale zara \\
\hline 10 & Bothrops alcatraz & Bothrops caribbaeus & Crotalus lannomi \\
\hline 11 & Bothrops otavioi & Bitis inomata & Cerrophidion tzotzilonum \\
\hline 12 & Porthidium hespere & Crotalus tzabcan & Cerrophidion petlalcalensis \\
\hline 13 & Cerastes boehmei & Trimeresurus fasciatus & Bothriechis supraciliaris \\
\hline 14 & Trimeresurus mcgregori & Bitis armata & Vipera anatolica \\
\hline 15 & Montatheris hindii & Bitis schneideri & Bitis armata \\
\hline 16 & Vipera orlovi & Mixcoatlus barbouri & Bothrops aribbaeus \\
\hline 17 & Vipera anatolica & Vipera monticola & Mixcoathus browni \\
\hline 18 & Echis megalocephalus & Trimeresurus malcolmi & Lachesis melanocephala \\
\hline 19 & Atropoides indomitus & Causus defilippii & Porthidium hespere \\
\hline 20 & Cerrophidion tzotzilorum & Protobothrops cornutus & Montivipera albizona \\
\hline 21 & Crotalus pusillus & Atropoides picadoi & Crotalus pusillus \\
\hline 22 & Gloydius lijianlii & Bothrops alcatraz & Vipera monticola \\
\hline 23 & Protobothrops dabieshanensis & Atheris chlorechis & Trimeresunus mcgregori \\
\hline 24 & Bothrops muriciensis & Protobothrops sieversonum & Bitis worthingtoni \\
\hline 25 & Bothrops lanceolatus & Cerastes vipera & Bitis rhinoceros \\
\hline 26 & Crotalus lannomi & Crotalus adamanteus & Protobothrops sieversorum \\
\hline 27 & Gloydius liupanensis & Mixcoatlus melanurus & Vipera orlovi \\
\hline 28 & Trimeresurus nubeus & Mixcoatlus browni & Crotalus unicolor \\
\hline 29 & Crotalus armstrongi & Causus bilineatus & Trimeresunus truongsonensis \\
\hline 30 & Montivipera wagneri & Atheris barbouri & Bitis inomata \\
\hline
\end{tabular}

Our combined index summarises variation between the reactive (TI) and proactive (EED) approaches (Table 1; Supplementary Material). Unsurprisingly, species richness weighted by the combined index (Fig. $1 \mathrm{G} / \mathrm{H}$ ) correlates strongly with both TI and EED, as well as overall species richness.

\section{Discussion}

Our analyses reveal both important challenges and promising opportunities for global viper conservation. Worryingly, the risk of extinction for vipers is higher than expected (e.g., Böhm et al., 2013; Tolley et al., 2016) and the gaps in our knowledge of taxonomic status and even basic biology limit our application of prioritisation indices to many species and undoubtedly our 
ability to conserve vipers in general. Moreover, the spatial arrangements of priority hotspots (independent of the index adopted) include multiple, isolated, idiosyncratically-distributed clusters for which generalised planning is likely to be challenging. Finally, nearly half of all species for which we had sufficient data to calculate TI, but that are currently listed as Data Deficient by the IUCN, appear to be of conservation concern, along with several others that have yet to be formally assessed. This emphasises the need for clade-specific assessments because a global analysis of Data Deficient species suggested $19 \%$ to be actually threatened (Bland and Böhm, 2016). Positively however, we identify several large nodes of high conservation priority for which generalised conservation action might be appropriate. Moreover, we show that our prioritisation indices are strongly influenced by species richness, such that using species richness as one of the proxies for conservation prioritisation is likely to be valuable.

\subsection{Viper species richness and conservation priority areas}

Species richness is commonly used as a measure of biodiversity to prioritise conservation planning, predominantly because it is relatively easy to measure at broad scales. However, recent assessments have noted a weak correlation of overall species richness with richness of endemic or threatened species (Orme et al., 2005; Lamoreux et al., 2006; Jenkins et al., 2013). Thus, it is noteworthy that both our TI and EED hotspot analysis revealed large clusters of high species richness. Our global pattern of viper species richness broadly reflects other venomous snake studies (Reed, 2003; Terribile et al., 2009) and provides a valuable starting point for identifying global conservation priority areas. The fact that both TI- and EED-weighted species richness maps showed global patterns that were largely congruent with overall species richness suggests that in the absence of information regarding individual species, species richness provides a useful rule of thumb for prioritising conservation areas for vipers.

Imperfect correlation among hotspots emphasises differences between the reactive and proactive indices. Hotspot analysis derived from the combined TI and EED indices balances these differences, and identified several minor nodes for conservation prioritisation globally. More importantly, our analysis identifies major regions for conservation action in North America, Mesoamerica, South America, Africa, and Asia (Fig .1). We recommend that these large nodes be subject to regional specific conservation planning in order to maximise viper conservation within each region. These nodes, when combined with species-specific priority scores (below), have the potential to significantly boost coordinated viper conservation planning efforts globally.

\subsection{Species priorities}

Our presentation of species-specific conservation priorities (Table 1; Supplementary Material) ranks species relative to other vipers to identify particular species where conservation efforts are likely to produce the greatest contribution to global viper conservation. Indeed, conservation and natural history research that focuses on target viper species already exist. Examples include work on Crotalus unicolor (Odum and Reinert, 2015), island vipers from south-eastern Brazil (Bataus and Reis, 2011), Armenian vipers (Ettling et al., 2015; Aghasyan, 2006) and 
Vipera ursinii in Hungary (e.g. Péchy et al., 2015) and France (http://www.vipereorsini.com/fr/). The Life project in Hungary has incorporated land protection, habitat restoration, creation of a Hungarian meadow viper conservation and exhibition centre, captive breeding and repatriation, monitoring, research, and education outreach to save the Hungarian meadow viper (e.g., Újvári et al., 2000; Edgar and Bird, 2006). Importantly, we propose that our ranking be used to direct similar potential conservation work and research, and help local conservation practitioners motivate for conservation of particular habitats or protection of individual species.

\subsection{TI and the Red List}

Our TI results broadly mirror Red List categories (Fig. 2). Our goal was not to replicate the Red List assessment with TI, but rather provide a complementary perspective on threat assessment. Indeed, the extent to which our TI measures agree with current Red List assessment can provide valuable insight into species that may not yet have been assessed, or have been incorrectly assessed, during the Red List process. In this context, we find that a large proportion of Not Assessed or Data Deficient species score higher than the threshold for likely threat status (0.75) on the TI and should be considered in future conservation planning. Conversely, several species currently considered threatened (CR, EN, or VU) were allocated low TI scores. In these cases we recommend critical examination of those assessments to ensure that the true conservation status of those species are accurately portrayed.

\subsection{Challenges to viper conservation}

4.4.1. Gaps in knowledge

Compiling our prioritisation database highlighted several major gaps in the knowledge needed to appropriately conserve vipers. These gaps should be used to direct future research. Our ED analysis was based on the most recent and complete molecular phylogeny for vipers (Alencar et al., in review), a phylogeny missing approximately 20\% of all known species. Several of the species missing from our phylogeny are poorly known in general, and for several of these their validity as a species (and thus their conservation priority; Bickford et al., 2007; Isaac et al., 2004) is questionable. Missing species unsurprisingly occurred in species rich, but poorly developed regions of the globe (Table 2). We strongly advocate work that aims to assess the taxonomic validity of these species (see Supplementary Material) so that adequate conservation planning, if required, can be initiated.

Our analysis also highlighted the enormity of the gaps in basic biological information regarding most vipers. Although traits related to morphology are relatively well-known (98\% of species in our database include measures of BS), natural history information regarding fecundity (67\% of species in our database include measures of MF) or diet (80\% of species in our database include measures of DS) were relatively incomplete. Moreover, many of the species for which natural history data are available are represented by no more than one or two publications that often focus on individual natural history observations rather than comprehensive dietary or reproductive studies. Several genera were particularly poorly known: we lacked either 
fecundity or dietary information for nine of the 16 species of Atheris, 7 of the 11 species of Echis, and 22 of the 44 species of Bothrops. Moreover, information regarding how these species will respond to landscape and climate change were also scarce given that quantitative assessment of such responses are almost entirely absent for vipers. We relied on expert opinion to estimate our AAH metric. However, gaps in our knowledge prevented us from assigning AAH scores for 87 species (26\%). Geographically, these gaps in knowledge were unsurprisingly greatest in developing regions (Table 2), similar to other reptile taxa (e.g. Meiri and Chapple, in this issue).

\begin{tabular}{|c|c|c|c|c|c|c|c|}
\hline Measure & North America & Mesoamerica & South America & Europe & Middle East & Africa & Asia \\
\hline Species richness & 25 & 85 & 55 & 17 & 34 & 49 & 100 \\
\hline Phylogeny & $2(8 \%)$ & $11(13 \%)$ & $14(25 \%)$ & $0(0 \%)$ & $5(15 \%)$ & 17 (35\%) & 23 (23\%) \\
\hline Fecundity & $2(8 \%)$ & $33(39 \%)$ & $23(42 \%)$ & $0(0 \%)$ & $12(35 \%)$ & $16(33 \%)$ & $28(28 \%)$ \\
\hline Diet & $0(0 \%)$ & $13(15 \%)$ & $21(38 \%)$ & $0(0 \%)$ & $2(24 \%)$ & $11(22 \%)$ & 15 (15\%) \\
\hline AAH & $2(8 \%)$ & $34(40 \%)$ & $18(33 \%)$ & $1(6 \%)$ & $4(12 \%)$ & $23(47 \%)$ & $8(8 \%)$ \\
\hline
\end{tabular}

The lack of demographic data for viper populations severely hinders effective conservation planning. While population estimates are available for several species of vipers (see for example Reading et al., 2010), these tend to be North American, African, or European species. Moreover, relatively few studies are longitudinal in nature which, when combined with low detection probabilities for most snakes (Seigel, 1993; Kéry, 2002; Durso et al., 2011), severely limits our ability to detect long-term changes in populations. While notable local-scale exceptions exist-long-term monitoring of Vipera ursinii in France (Baron et al., 1996; Ferriere et al., 1996), Crotalus horridus in the north-eastern United States (Brown et al., 2007), Gloydius shedaoensis in China (Sun et al., 2001), and Vipera aspis in Switzerland (Flatt et al., 1997)-our knowledge of global population trends is lacking for nearly all species.

\subsubsection{Threats to vipers}

The single biggest threat to vipers globally is the continued loss, degradation, and fragmentation of suitable habitat (Gibbons et al., 2000; Dirzo and Raven, 2003; Fischer and Lindenmayer, 2007). Some vipers may be particularly sensitive to habitat loss (e.g. Luiselli and Capizzi, 1997; Waldron et al., 2006; Tuniev and Tuniev, 2009; Ettling et al., 2015) due to slow growth, low levels of reproduction (e.g., Webb et al., 2002), their often specialized diet (e.g. Luiselli and Capizzi, 1997), or a high degree of habitat specialisation (Zamudio and Greene, 1997; Waldron et al., 2006; Santos and Poquet, 2010; Leão et al., 2014). Isolated populations of vipers have low genetic diversity and may be at increased risk of extinction (Madsen et al., 1996; Újvári et al., 2002; Ursenbacher et al., 2008; Clark et al., 2011). Fragmentation by unsuitable habitats, such as agricultural landscapes devoid of structures (e.g., Völkl and Thiesmeier, 2002) may be particularly problematic for vipers. Moreover, linear barriers such as walls (Madsen and Újvári, 2011) or roads (Andrews and Gibbons, 2005) may limit the movement of vipers. Thus habitat fragmentation by roads 
has the potential to rapidly degrade genetic diversity (Clark et al., 2010; DiLeo et al., 2013; Bushar et al., 2015; but see Weyer et al., 2014).

A range of viper species are traded globally, and while many of them are derived from captive populations, wild snakes are also traded with unknown impacts on their populations (IUCN, 2015b). In general, such collection and illegal trade is particularly relevant for highly threatened insular species (e.g., Bothrops insularis, Martins et al., 2008; Guimaraes et al., 2014). Of concern is that only Crotalus durissus, Daboia russelii, Montivipera wagneri, Protobothrops mangshanensis, and Vipera ursinii are currently protected by the Convention on International Trade in Endangered Species of Wild Flora and Fauna (CITES, 2015), severely hindering the ability of nations to limit overexploitation. While some experts deny that international trade could threaten free-ranging populations of African vipers (see in Crnobrnja-Isailović, 2014), we cannot neglect recent reports of illegal collection of viper species such as Atheris desaixi in Kenya (MBZ, 2012) or Atheris matildae in Tanzania (Menegon et al., 2011).

In many parts of the world humans hunt vipers for food (Klemens and Thorbjarnarson, 1995). Bitis arietans (Brugiere and Magassouba, 2009), Bitis gabonica, and Bitis nasicornis (Brugiere and Magassouba, 2009; Eniang et al., 2006) are frequently consumed for sustenance, Gloydius himalayanus is eaten primarily for medical treatment (Pushpangadan et al., 2014), and the impacts of such exploitation remain unknown. Viper venom is a sophisticated product of biological evolution (Calvete, 2013), with a wide spectrum of applications in medicine, pharmacology, and immunology (Jesupret et al., 2014). The collection of vipers for venom extraction has resulted in potential overcollection with unknown demographic effects for several species including Vipera ammodytes, Bothrops insularis, Daboia russelii, and Pseudocerastes persicus (Ajtić, 2008; Martins et al., 2008; Pushpangadan et al., 2014; IUCN, 2015b).

Direct persecution, primarily driven by fear and superstition (Weatherhead and Madsen, 2009), continues to pose a threat to many vipers globally. While education can change people's attitude toward venomous snakes (Burghardt et al., 2009; Ballouard et al., 2013), the prevalence of direct persecution in some parts of the world remains rampant: large scale bounty hunts were common in Europe (e.g. see Völkl and Thiesmeier, 2002 for Germany or Tóth et al., 2010 for Hungary) and parts of Japan (Sasaki et al., 2010); the deliberate killing of vipers was recorded in Tanzania (Nonga and Haruna, 2015) and in the Western Balkans (Jelić et al., 2013); and the collection of Crotalus to supply rattlesnake roundups in several US states continues (Fitzgerald and Painter, 2000).

The impact of introduced species, particularly mammals, on viper populations remains poorly quantified but is potentially problematic for island fauna and for endemic or narrowly distributed species. The small Indian mongoose (Herpestes auropunctatus) has 
been introduced as biocontrol on several islands with endemic vipers in Japan (Watari et al., 2013), on Martinique and St. Lucia (Barun et al., 2011), and on several Adriatic islands (Barun et al., 2010). Although mongooses have had long-term negative effects on local insular viper populations in Croatia (Barun et al., 2010), their effect on viper populations in Japan has been equivocal (Watari et al., 2013). Pigs (Sus scrofa) may also impact viper populations where they have been introduced (Klauber, 1972), sometimes as biocontrol of viper populations (Schuyler et al., 2002). Although domestic cats (Felis catus) have the potential to impact snake populations (Medina et al., 2011), there are no published reports of their impact on viper populations (but see Grismer, 2002; Arnaud et al., 2008, for records of Crotalus catalinensis remains in feral cat scat).

Some vipers will undoubtedly face increased extinction risk due to the rapidly changing climate stemming from anthropogenic greenhouse gas emissions. In vipers from temperate regions, a warming climate could affect functionality of immune systems (Kobolkuti et al., 2012), cause changes in life-history traits (Forsman, 1993; Lindell, 1997; Altwegg et al., 2005), and negatively impact some viper populations (Brito et al., 2011; Le Galliard et al., 2012). Moreover, long-term studies on Italian Vipera aspis revealed considerable phenological changes in response to global warming (Rugiero et al., 2013), with species with narrow geographical ranges at particular risk (e.g., Davis et al., 2015). While future climatic conditions could threaten some tropical vipers by narrowing their climatic niche (Bombi et al., 2011), others are likely to benefit (Huang et al., 2013).

\subsection{Recommendations}

Relative to other major groups of vertebrates, there have been few efforts to conserve declining viper species. To date, conservation work has been primarily conducted by individuals associated with universities, museums, or zoos and there are few examples of broader programs incorporating multiple institutions to conserve an endangered viper species. More recently, the IUCN Viper Specialist Group (VSG) was formed to bring together a global network of viper conservation biologists. The VSG is currently in the process of conducting status assessments for all viper species and is building a network of members to facilitate globally coordinated viper conservation efforts. The vision is to build a comprehensive "Action Plan" for all viper species-a living document which brings together examples from successful conservation work, highlights useful methods, addresses major conservation challenges in detail, and provides guidelines and resources for viper conservation.

We have prioritized key species and regions for conservation action by identifying important gaps in our understanding of viper biology and highlighting the species and regions for which conservation action is likely to add the greatest value in a global context. Moreover, our work presented in this paper provides not only a valuable gap analysis regarding not only regional and species-specific conservation priorities, but also a useful bibliographic contribution to globalised viper conservation in the future. Through the 
VSG, we hope to build on these findings, as well as the outcomes from alternative approaches to conservation planning, and move toward a global framework for viper conservation through the implementation of region-specific analyses and, eventually, conservation action plans for vipers in every region of the world.

\section{Acknowledgements}

We would like to thank the special issue editors for the opportunity to submit this manuscript. Reid Tingley provided useful comments on a previous version of this manuscript. JCI thanks Olexander Zinenko, Fernando Martinez-Freiria, José-Carlos Brito, Sylvain Ursenbacher and Stephen Roussos for comments on species traits and MESTD of the Republic of Serbia (grants OI173025 and OI1613051) for support. JSR thanks Alondra Encarnación-Luevano an Ernestina Meza-Rangel for comments and help with references, Universidad Autónoma de Zacatecas and a NPTC grant from PROMEP. LRVA was supported by a PhD fellowship scholarship (FAPESP 2012/02038-2). KM would like to acknowledge partial support by the PAPD program. MM thanks FAPESP for a grant (2011/50206-9) and CNPq for a fellowship (302953/2012-4). PS would like to acknowledge the support of the Environment AgencyABU DHABI to viper conservation efforts. BM thanks The Mohammed bin Zayed Species Conservation Fund (152510848).

\section{Appendix A. Supplementary data}

Supplementary data to this article can be found online at http://dx.doi.org/10.1016/j.biocon.2016.05.004. 


\section{References}

Aghasyan, L., 2006. Development of conservation measures for the Darevsky's viper in the Caucasus. Final Report. The BP Conservation Programme. Yerevan, Armenia.

Ajtić, R., 2008. Nose-horned viper (Vipera ammodytes) conservation problems in Serbia. Nat. Protoc. 60, 319-326 (In Serbian, with Summary in English).

Alencar, L.R.V., Quental, T.B., Grazziotin, F.G., Alfaro, M.L., Martins, M., Venzon, M., Zaher, H., Diversification in vipers: phylogenetic relationships, time of divergence, and shifts in speciation rates. Mol. Phylogenet. Evol. (in review)

Altwegg, R., Dummermuth, S., Anholt, B.R., Flatt, T., 2005. Winter weather affects asp viper Vipera aspis population dynamics through susceptible juveniles. Oikos 110, 55-66.

Andrews, K., Gibbons, J., 2005. How do highways influence snake movement? Behavioral responses to roads and vehicles. Copeia 2005, 772-782.

Arnaud, G., Martins, M., Burguete-Trujillo, L., Hernández-Rodríguez, I., AvilaVillegas, H., Murillo-Quero, R., Quijada-Mascareñas, A., 2008. Historia natural de la serpiente de cascabel Crotalus catalinensis, endémica de la isla Santa Catalina, Golfo de California. In: Flores-Campaña, L.M. (Ed.), Estudios de las islas del Golfo de California. Universidad Autónoma de Sinaloa, Culiacán, Sinaloa, México, pp. 93-100.

Ballouard, J.M., Ajtić, R., Balint, H., Brito, J.C., Crnobrnja-Isailović, J., Elmouden, E.L., Erdogan, M., Feriche, M., Pleguezuelos, J.M., Prokov, P., Sanchez, A., Santos, X., Slimani, T., Sterijovski, B., Tomović, L., Usak, M., Zuffi, M., Bonnet, X., 2013. Schoolchildren and one of the most unpopular animals: are they ready to protect snakes? Anthrozoös 26, 93-109.

Baron, J.-P., Ferriere, R., Clobert, J., Saint-Girons, H., 1996. Life-history of Vipera ursinii ursinii at Mont Ventoux (France). C. R. Acad. Sc. Fr. Paris Life Sci. 319, 57-69.

Barun, A., Simberloff, D., Budinski, I., 2010. Impact of the small Indian mongoose on native amphibians and reptiles of the Adriatic islands, Croatia. Anim. Conserv. 13, 549-555. Barun, A., Hanson, C.C., Campbell, K.J., Simberloff, D., 2011. A review of small Indian mongoose management and eradications on islands. In: Veitch, C.R., Clout, M.N., Towns, D.R. (Eds.), Island Invasives: Eradication and Management. IUCN, Gland, pp. 17-25.

Bataus, Y., Reis, M.L., 2011. Plano de ação nacional para a conservação da herpetofauna insular ameaçada de extinção. Instituto Chico Mendes de Conservação da Biodiversidade, ICMBio, Brasília (124 pp).

Beaupre, S.J., Duvall, D., 1998. The integrative biology of rattlesnakes: contributions to ecology and evolution. Bioscience 48, 531-538.

Bickford, D., Lohman, D.J., Sodhi, N.S., Ng, P.K.L., Meier, R., Winker, K., Ingram, K.K., Das, I., 2007. Cryptic species as a window on diversity and conservation. Trends Ecol. Evol. 22, 148-155. 
Bland, L.M., Böhm, M., 2016. Overcoming Data Deficiency in Reptiles (SAME ISSUE).

Böhm, M., Collen, B., Baillie, J.E.M., Bowles, P., Chanson, J., Cox, N., Hammerson, G., Hoffmann, M., Livingstone, S.R., Rama, M., Rhodin, A.G.J., Stuart, S.N., van Dijk, P.P., Young, B.E., Afuang, L.E., Aghasyan, A., García, A., Aguilar, C., Ajtić, R., Akarsu, F., Alencar, L.R.V., Allison, A., Ananjeva, N., Anderson, S., Andrén, C., Ariano-Sánchez, D., Arredondo, J.C., Auliya, M., Austin, C.C., Avci, A., Baker, P.J., Barreto-Lima, A.F., BarrioAmorós, C.L., Basu, D., Bates, M.F., Batistella, A., Bauer, A., Bennett, D., Böhme, W., Broadley, D., Brown, R., Burgess, J., Captain, A., Carreira, S., del Rosario Castañeda, M., Castro, F., Catenazzi, A., Cedeño-Vázquez, J.R., Chapple, D.G., Cheylan, M., Cisneros-Heredia, D.F., Cogalniceanu, D., Cogger, H., Corti, C., Costa, G.C., Couper, P.J., Courtney, T., CrnobrnjaIsailović, J., Crochet, P.-A., Crother, B., Cruz, F., Daltry, J.C., Daniels, R.J.R., Das, I., de Silva, A., Diesmos, A.:.C., Dirksen, L., Doan, T.M., Dodd Jr., C.K., Doody, J.S., Dorcas, M.E., Duarte de Barros Filho, J., Egan, V.T., El Mouden, E.H., Embert, D., Espinoza, R.E., Fallabrino, A., Feng, X., Feng, Z.-J., Fitzgerald, L., Flores-Villela, O., França, F.G.R., Frost, D., Gadsden, H., Gamble, T., Ganesh, S.R., Garcia, M.A., García-Pérez, J.E., Gatus, J., Gaulke, M., Geniez, P., Georges, A., Gerlach, J., Goldberg, S., Gonzalez, J.C.T., Gower, D.J., Grant, T., Greenbaum, E., Grieco, C., Guo, P., Hamilton, A.M., Hare, K., Hedges, S.B., Heideman, N., Hilton-Taylor, C., Hitchmough, R., Hollingsworth, B., Hutchinson, M., Ineich, I., Iverson, J., Jaksic, F.M., Jenkins, R., Joger, U., Jose, R., Kaska, Y., Kaya, U., Keogh, J.S., Köhler, G., Kuchling, G., Kumlutas, Y., Kwet, A., La Marca, E., Lamar, W., Lane, A., Lardner, B., Latta, C., Latta, G., Lau, M., Lavin, P., Lawson, D., LeBreton, M., Lehr, E., Limpus, D., Lipczynski, N., Lobo, A.S., López-Luna, M.A., Luiselli, L., Lukoschek, V., Lundberg, M., Lymberakis, P., Macey, R., Magnusson, W.E., Mahler, D.L., Malhotra, A., Mariaux, J., Maritz, B., Marques, O.A.V., Márquez, R., Martins, M., Masterson, G., Mateo, J.A., Mathew, R., Mathews, N., Mayer, G., McCranie, J.R., Measey, G.J., Mendoza-Quijano, F., Menegon, M., Métrailler, S., Milton, D.A., Montgomery, C., Morato, S.A.A., Mott, T., Muñoz- Alonso, A., Murphy, J., Nguyen, T.Q., Nilson, G., Nogueira, C., Núñez, H., Orlov, N., Ota, H., Ottenwalder, J., Papenfuss, T., Pasachnik, S., Passos, P., Pauwels, O.S.G., Pérez-Buitrago, N., Pérez-Mellado, V., Pianka, E.R., Pleguezuelos, J., Pollock, C., Ponce-Campos, P., Powell, R., Pupin, F., Quintero Díaz, G.E., Radder, R., Ramer, J., Rasmussen, A.R., Raxworthy, C., Reynolds, R., Richman, N., Rico, E.L., Riservato, E., Rivas, G., da Rocha, P.L.B., Rödel, M.-O., Rodríguez Schettino, L., Roosenburg, W.M., Ross, J.P., Sadek, R., Sanders, K., Santos-Barrera, G., Schleich, H.H., Schmidt, B.R., Schmitz, A., Sharifi, M., Shea, G., Shi, H.-T., Shine, R., Sindaco, R., Slimani, T., Somaweera, R., Spawls, S., Stafford, P., Stuebing, 
R., Sweet, S., Sy, E., Temple, H.J., Tognelli, M.F., Tolley, K., Tolson, P.J., Tuniyev, B., Tuniyev, S., Üzümae, N., van Buurt, G., Van Sluys, M., Velasco, A., Vences, M., Veselý, M., Vinke, S., Vinke, T., Vogel, G., Vogrin, M., Vogt, R.C., Wearn, O.R., Werner, Y.L., Whiting, M.J., Wiewandt, T., Wilkinson, J., Wilson, B., Wren, S., Zamin, T., Zhou, K., Zug, G., 2013. The conservation status of the world's reptiles. Biol. Conserv. 157, 372-385.

Bombi, P., Akani, G.C., Ebere, N., Luiselli, L., 2011. Potential effects of climate change on high- and low abundance populations of the Gaboon viper (Bitis gabonica) and the nose-horned viper (B. nasicornis) in southern Nigeria. Herpetol. J. 21, 59-64.

Brito, J.C., Fahd, S., Martinez-Freiria, F., Tarroso, P., Larbes, S., Pleguezuelos, J.M., Santos, X., 2011. Climate change and peripheral populations: predictions for a relict Mediterranean viper. Acta Herpet. 6, 105-118.

Brooks, T.M., Mittermeier, R.A., da Fonseca, G.A.B., Gerlach, J., Hoffmann, M., Lamoreux, J.F., Mittermeier, C.G., Pilgrim, J.D., Rodrigues, A.S.L., 2006. Global biodiversity conservation priorities. Science 313, 58-61.

Brown, W.S., Kéry, M., Hines, J.E., 2007. Survival of timber rattlesnakes (Crotalus horridus) estimated by capture-recapture models in relation to age, sex, color morph, time, and birthplace. Copeia 2007, 656-671.

Brugiere, D., Magassouba, B., 2009. Pattern and sustainability of the bushmeat trade in the Haut Niger National Park, Republic of Guinea. Afr. J. Ecol. 44, 630639.

Burghardt, G.M., Murphy, J.B., Chiszar, D., Hutchins, M., 2009. Combating ophiophobia: origins, treatment, education and conservation tools. In: Mullin, S.J., Seigel, R.A. (Eds.), Snakes: Ecology and Conservation. Cornell University Press, Ithaca, New York, pp. 262-280.

Bushar, L.M., Bhatt, N., Dunlop, M.C., Schocklin, C., 2015. Population isolation and genetic subdivision of timber rattlesnakes (Crotalus horridus) in the New Jersey pine barrens. Herpetologica 7, 203-211.

Calvete, J.J., 2013. Snake venomics: from the inventory of toxins to biology. Toxicon 75, 44-62.

Campbell, J.A., Lamar, W.W., 2004. The Venomous Reptiles of the Western Hemisphere. Cornell University Press, Ithaca, New York.

Chippaux, J.-P., 1998. Snake-bites: appraisal of the global situation. Bull. WHO $76,515-524$.

CITES, 2015. Convention on international trade in endangered species of wild Fauna and Flora. Available on https://www.cites.org/eng (Consulted September 17, 2015).

Clark, R.W., Brown. W., S., Stechert, R., Zamudio, K.R., 2010. Roads, interrupted dispersal, and genetic diversity in timber rattlesnakes. Conserv. Biol. 24, 1059-1069. 
Clark, R.W., Marchand, M.N., Clifford, B.J., Stechert, R., Stephens, S., 2011. Decline of an isolated timber rattlesnake (Crotalus horridus) population: interactions between climate change, disease, and loss of genetic diversity. Biol. Conserv. 144, 886-891.

Collen, B., Turvey, S.T., Waterman, C., Meredith, H.M.R., Kuhn, T.S., Baillie, J.E.M., Isaac, N.J.B., 2011. Investing in evolutionary history: implementing a phylogenetic approach for mammal conservation. Philos. T. Roy. Soc. B 366, 2611-2622.

Crnobrnja-Isailović, J., 2014. VSG Meeting at 4th Biology of Vipers Conference in Athens, Greece. A report. http://www.oriannesociety.org/blog/vsg-meeting4th-biology-vipers-conference-athens-greece.

Cundall, D., 2002. Envenomation strategies, head form, and feeding ecology in vipers. In: Höggren, M., Douglas, M.E., Greene, H.W. (Eds.), Schuett, G.W.Biology of the Vipers. Eagle Mountain Publishing, pp. 149-161

Cundall, D., Greene, H.W., 200o. Feeding in snakes. In: Schwenk, K. (Ed.), Feeding: Form, Function, and Evolution in Tetrapod Vertebrates. Academic Press, New York, pp. 293-333.

Curnick, D.J., Head, C.E.I., Huang, D., Crabbe, M.J.C., Gollock, M., Hoeksema, B.W., Johnson, K.G., Jones, R., Koldewey, H.J., Obura, D.O., Rosen, B.R., Smith, D.J., Taylor, M.L., Turner, J.R., Wren, S., Redding, D.W., 2015. Setting evolutionary-based conservation priorities for a phylogenetically data-poor taxonomic group (Scleractinia). Anim. Conserv. 18 (313-312).

Davis, K.F., Rulli, M.C., D'Odorico, P., 2015. The global land rush and climate change. Earth's Future 3, 298-311.

DiLeo, M.F., Rouse, J.D., Dávila, J.A., Lougheed, S.C., 2013. The influence of landscape on gene flow in the eastern massasauga rattlesnake (Sistrurus c. catenatus): insight from computer simulations. Mol. Ecol. 22, 4483-4498.

Dirzo, R., Raven, P.H., 2003. Global state of biodiversity and loss. Annu. Rev. Environ. Resour. 28, 137-167.

Dodd Jr., C.K., 1987. Status, conservation, and management. In: Seigel, R.A., Collins, J.T., Novak, S.S. (Eds.), Snakes: Ecology and Evolutionary Biology. MacMillan Publishing Co., New York, pp. 478-513.

Durso, A.M., Willson, J.D., Winne, C.T., 2011. Needles in haystacks: estimating detection probability and occupancy of rare and cryptic snakes. Biol. Conserv. 144, 1508-1515. Edgar, P., Bird, D.R., 2006. Action plan for the conservation of the meadow viper (Vipera ursinii) in Europe. Convention on the Conservation of European Wildlife and Natural Habitats Standing Committee, 26th Meeting, Strasbourg, 27-29 November, pp. 27-29.

Eniang, E.A., Egwali, E.C., Luiselli, L.M., Ayodele, I.A., Akani, G.C., Pacini, N., 2006. Snake Bushmeat From the Forest Markets of South-eastern Nigeria. Natura, Soc it Sci nat Museo civ Stor nat Milano 95, pp. 33-46. 
Ettling, J.A., Aghasyan, A.L., Aghasyan, L.A., 2015. The conservation of rare Armenian vipers Montivipera raddei and Pelias spp. Int. Zoo Yearb. 49, 8188.

Fenwick, A.M., Greene, H.W., Parkinson, C.L., 2011. The serpent and the egg: unidirectional evolution of reproductive mode in vipers? J. Zool. Syst. Evol. Res. 50, 59-66.

Ferriere, R., Sarrazin, F., Legendre, S., Baron, J.P., 1996. Matrix population models applied to viability analysis and conservation: theory and practice using the ULM software. Acta Oecol. 17, 629-656.

Filippi, E., Luiselli, L., 2000. Status of the Italian snake fauna and assessment of conservation threats. Biol. Conserv. 93, 219-225.

Fischer, J., Lindenmayer, D.B., 2007. Landscape modification and habitat fragmentation: a synthesis. Glob. Ecol. Biogeogr. 16, 265-280.

Fitzgerald, L.A., Painter, C.W., 2000. Rattlesnake commercialization: long-term trends, issues, and implications for conservation. Wildl. Soc. Bull. 28, 235253.

Flatt, T., Dummermuth, S., Anholt, B.R., 1997. Mark-recapture estimates of survival in populations of the asp viper, Vipera aspis aspis. J. Herpetol. 31, 558-564.

Forsman, A., 1993. Survival in relation to body size and growth rate in the adder, Vipera berus. J. Anim. Ecol. 62, 647-655.

Gaiarsa, M.P., Alencar, L.R.V., Valdujo, P.H., Tambosi, L.R., Martins, M., 2015. Setting conservation priorities within monophyletic groups: an integrative approach. J. Nat. Conserv. 24, 49-55.

Gibbons, J.W., Scott, D.E., Ryan, T.J., Buhlmann, K.A., Tuberville, T.D., Metts, B.S., Greene, J.L., Mills, T., Leiden, Y., Poppy, S., Winne, C.T., 200o. The global decline of reptiles, déjà vu amphibians. Bioscience 50, 653-666.

Greene, H.W., 1983. Dietary correlates of the origin and radiation of snakes. Am. Zool. 23, 431-441.

Greene, H.W., 1997. Snakes - The Evolution of Mystery in Nature. University of California Press, Berkeley and Los Angeles, California.

Greene, H.W., Campbell, J.A., 1992. The future of pitvipers. In: Campbell, J.A., Brodie Jr., E.D. (Eds.), Biology of the Pitvipers. Selva, Tyler, Texas, pp. 421427.

Greene, H.W., May, P., Hardy Sr., D.L., Sciturro, J., Farrell, T., 2002. Parental behavior by vipers. In: Höggren, M., Douglas, M.E., Greene, H.W. (Eds.), Schuett, G.W.Biology of the Vipers. Eagle Mountain Publishing, pp. 179205

Grenyer, R., Orme, C.D.L., Jackson, S.F., Thomas, G.H., Davies, R.G., Davies, T.J., Jones, K.E., Olson, V.A., Ridgley, R.S., Rasmussen, P.C., Ding, T.-S., Bennet, P.M., Blackburn, T.M., Gaston, K.J., Gittleman, J.L., Owens, I.P., 2006. Global distribution and conservation of rare and threatened vertebrates. Nature 444, 93-96. 
Grismer, L.L., 2002. Amphibians and Reptiles of Baja California, Including Its Pacific Islands and the Islands in the Sea of Cortés. University California Press, Berkeley, CA, USA.

Guimaraes, M., Munguía-Steyer, R., Doherty Jr., P.F., Martins, M., Sawaya, R.J., 2014. Population dynamics of the critically endangered golden lancehead pitviper, Bothrops insularis: stability or decline? PLoS One 9, e95203.

Gumprecht, A., Tillack, F., Orlov, N.L., Captain, A., Ryabov, S., 2004. Asian Pitvipers. Geitje Books, Berlin.

Gutiérrez, J.M., Williams, D., Fan, H.W., Warrell, D.A., 2010. Snakebite envenoming from a global perspective: towards an integrated approach. Toxicon $56,1223-1235$.

Huang, S.-P., Chiou, C.-R., Lin, T.-E., Tu, M.-C., Lin., C.-C., Porter, W.P., 2013. Future advantages in energetics, activity time, and habitats predicted in a high-altitude pit viper with climate warming. Funct. Ecol. 27, 446-458.

Isaac, N.J., Mallet, J., Mace, G.M., 2004. Taxonomic inflation: its influence on macroecology and conservation. Trends Ecol. Evol. 19, 464-469.

Isaac, N.J.B., Turvey, S.T., Collen, B., Waterman, C., Baillie, J.E.M., 2007. Mammals on the EDGE: conservation priorities based on threat and phylogeny. PLoS One 2, e296.

IUCN, 2015a. Red list of threatened species, version 2015-4. www.iucnredlist.org.

IUCN, 2015b. Red list assessment of Asian snake species decision 16.104. Interpretation and Implementation of the Convention. Species Trade and Conservation. Snake Trade and Conservation Management. 28th Meeting of the Animals Committee, 3oth August/3rd September 2015, Tel Aviv (Israel).

IUCN, UNEP-WCMC, 2015. The World Database on Protected Areas (WDPA) Accessed September 2015. UNEP-WCMC, Cambridge, UK (Available at: www.protectedplanet.net).

Jelić, D., Ajtić, R., Sterijovski, B., Crnobrnja-Isailović, J., Lelo, S., Tomović, L., 2013. Legal status and assessment of conservation threats to vipers (Reptilia: Squamata: Viperidae) of the Western and Central Balkans. Herpetol. Conserv. Biol. 8, 764-770.

Jenkins, C.N., Pimm, S.L., Joppa, L.N., 2013. Global patterns of terrestrial vertebrate diversity and conservation. Proc. Natl. Acad. Sci. 110, E2602-E2610.

Jesupret, C., Baumann, C., Jackson, T.N.W., Ali, S.A., Yang, D.C., Greisman, L., Kern, L., Steuten, J., Jouiaei, M., Casewell, N.R., Undheim, E.A.B., Koludarov, I., Debono, J., Dolyce, H.W., Low, D.H.W., Rossi, S., Panagides, N., Winter, K., Ignjatović, V., Summerhayes, R., Jones, A., Nouwens, A., Dunstan, N., Hodgson, W.C., Winkel, K.D., Monagle, P., Fry, B.G., 2014. Vintage venoms: proteomic and pharmacological stability of snake venoms stored for up to eight decades. J. Proteome 105, 285-294.

Kéry, M., 2002. Inferring the absence of a species: a case study of snakes. J. Wildl. Manag. 66, 330-338. 
Klauber, L.M., 1972. Rattlesnakes: Their Habits, Life-histories, and Influence on Mankind. second ed. University of California Press, Berkeley.

Klemens, M.W., Thorbjarnarson, J.B., 1995. Reptiles as a food resource. Biodivers. Conserv. 4, 281-298.

Kobolkuti, L., Cadar, D., Czirjak, G., Niculae, M., Kiss, T., Sandru, C., Spinu, M., 2012. The effects of environment and physiological cyclicity on the immune system of Viperinae. Sci. World J., 574867 http://dx.doi.org/10.1100/2012/574867 (6 pages).

Lamoreux, J.F., Morrison, J.C., Ricketts, T.H., Olson, D.M., Dinerstein, E., McKnight, M.W., Shugart, H.H., 2006. Global tests of biodiversity concordance and the importance of endemism. Nature 440, 212-214.

Le Galliard, J.-F., Massot, M., Baron, J.-P., Clobert, J., 2012. Ecological effects of climate change on European reptiles. In: Brodie, J., Post, E., Doak, D. (Eds.), Wildlife Conservation in a Changing Climate. University of Chicago Press, p. 179.

Leão, S.M., Pelegrin, N., Nogueira, C.C., Brandão, R.A., 2014. Natural history of Bothrops itapetiningae Boulenger, 1907 (Serpentes: Viperidae: Crotalinae), an endemic species of the Brazilian Cerrado. J. Herpetol. 48, 324-331.

Lindell, L.E., 1997. Annual variation in growth rate and body condition of adders, Vipera berus: effects of food availability and weather. Can. J. Zool. 75, 261270.

Luiselli, L., Capizzi, D., 1997. Influences of area, isolation and habitat features on distribution of snakes in Mediterranean fragmented woodlands. Biodivers. Conserv. 6, 1339-1351.

Madsen, T., Újvári, B., 2011. The potential demise of a population of adders (Vipera berus) in Smygehuk, Sweden. Herpetol. Conserv. Biol. 6, 72-74.

Madsen, T., Stille, B., Shine, R., 1996. Inbreeding depression in an isolated population of adders Vipera berus. Biol. Conserv. 75, 113-118.

Mallow, D., Ludwig, D., Nilson, G., 2003. True Vipers: Natural History and Toxinology of Old World Vipers. Krieger Publishing Company, Malabar, Florida.

Martins, M., Marques, O.A.V., Sazima, I., 2002. Ecological and phylogenetic correlates of feeding habits in Neotropical pitvipers (Genus Bothrops). In: Höggren, M., Douglas, M.E., Greene, H.W. (Eds.), Schuett, G.W.Biology of the Vipers. Eagle Mountain Publishing, pp. 307-328

Martins, M., Sawaya, R.J., Marques, O.A., 2008. A first estimate of the population size of the critically endangered lancehead, Bothrops insularis. S. Am. J. Herpetol. 3, 168-174.

May, R.M., 1990. Taxonomy as destiny. Nature 347, 129-130.

MBZ, 2012. The Mohamed Bin Zayed Species Conservation Fund Report on the Mt. Kenya Bush Viper (Atheris desaixi) Project Report 0905639, 8th September. 
Medina, F.M., Bonnaud, E., Vidal, E., Tershy, B.R., Zavaleta, E.S., Josh Donlan, C., Keitt, B.S., Le Corre, M., Horwath, S.V., Nogales, M., 2011. A global review of the impacts of invasive cats on island endangered vertebrates. Glob. Chang. Biol. 17, 3503-3510.

Meiri, S., Chapple, D.G., 2016. Biases in the Current Knowledge of Threat Status in Lizards, and Bridging the "Assessment Gap" (in this issue).

Menegon, M., Davenport, T.R.B., Howell, T.K., 2011. Description of a new and critically endangered species of Atheris (Serpentes: Viperidae) from the Southern Highlands of Tanzania, with an overview of the country's tree viper fauna. Zootaxa 3120, 43-54.

Morais, A.R., Siqueira, M.N., Lemes, P., Maciel, N.M., De Marco, P., Brito, D., 2013. Unraveling the conservation status of data deficient species. Biol. Conserv. 166 (98- 102.Br).

Myers, N., 1988. Threatened biotas: "hot spots" in tropical forests. Environmentalist 8, 187-208.

Myers, N., Mittermeier, R.A., Mittermeier, C.G., Da Fonseca, G.A., Kent, J., 2000. Biodiversity hotspots for conservation priorities. Nature 403, 853-858.

Nonga, H.E., Haruna, A., 2015. Assessment of human-snake interaction and its outcomes in Monduli District, northern Tanzania. Tanzan. J. Health Res. 17, $1-12$.

Norris, R., 2004. Venom poisoning by north American reptiles. In: Campbell, J.A., Lamar, W.W. (Eds.), The Venomous Reptiles of the Western Hemisphere. Cornell University Press, Ithaca, NY, pp. 683-708.

Nowak, E.M., Theimer, T.C., Schuett, G.W., 2008. Functional and numerical responses of predators: where do vipers fit in the traditional paradigms? Biol. Rev. 83, 601-620.

Odum, R.A., Reinert, H.K., 2015. The Aruba Island rattlesnake Crotalus unicolor species survival plan: a case history in ex situ and in situ conservation. Int. Zoo Yearb. 49, 104-112.

Olson, D.M., Dinerstein, E., Wikramanayake, E.D., Burgess, N.D., Powell, G.V.N., Underwood, E.C., D'Amico, J.A., Itoua, I., Strand, H.E., Morrison, J.C., Loucks, C.J., Allnutt, T.F., Ricketts, T.H., Kura, Y., Lamoreux, J.F., Wettengel, W.W., Hedao, P., Kassem, K.R., 2001. Terrestrial ecoregions of the world: a new map of life on earth. Bioscience 51, 933-938.

Orme, C.D.L., Davies, R.G., Burgess, M., Eigenbrod, F., Pickup, N., Olson, V.A., Webster, A.J., Ding, T.-S., Rasmussen, P.C., Ridgely, R.S., et al., 2005. Global hotspots of species richness are not congruent with endemism or threat. Nature 436, 1016-1019.

Orme, D., Freckleton, R., Thomas, G., Petzoldt, T., Fritz, S., Isaac, N., Pearse, W., 2013. Caper: comparative analyses of phylogenetics and evolution in $\mathrm{R}$. $\mathrm{R}$ package version 0.5.2. http://CRAN.R-project.org/package=caper.

Péchy, T., Halpern, B., Sós, E., Walzer, C., 2015. Conservation of the Hungarian meadow viper Vipera ursinii rakosiensis. Int. Zoo Yearb. 49, 89-103. 
Petchey, O.L., Gaston, K.J., 2006. Functional diversity: back to basics and looking forward. Ecol. Lett. 9, 741-758.

Pushpangadan, P., George, V., Sreedevi, P., Ijinu, T.P., Ninawe, A., 2014. Ethnozoological knowledge of Indian scheduled tribe, scheduled caste and rural communities. Indian J. Tradit. Knowl. 13, 735-741.

Pyron, R.A., Burbrink, F.T., Wiens, J.J., 2013. A phylogeny and revised classification of Squamata, including 4161 species of lizards and snakes. BMC Evol. Biol. 13, 93.

R Core Team, 2015. R: A Language and Environment for Statistical Computing. R Foundation for Statistical Computing, Vienna, Austria (URL http://www.Rproject.org/).

Reading, C.J., Luiselli, L.M., Akani, G.C., Bonnet, X., Amori, G., Ballouard, J.M., Filippi, E., Naulleau, G., Pearson, D., Rugiero, L., 2010. Are snake populations in widespread decline? Biol. Lett. 6, 777-780.

Reed, R.N., 2003. Interspecific patterns of species richness, geographic range size, and body size among New World venomous snakes. Ecography 26, 107-117.

Reed, R.N., Shine, R., 2002. Lying in wait for extinction: ecological correlates of conservation status among Australian elapid snakes. Conserv. Biol. 16, 451-461.

Rugiero, L., Milana, G., Petrozzi, F., Capula, M., Luiselli, L., 2013. Climate-change-related shifts in annual phenology of a temperate snake during the last 20 years. Acta Oecol. 51, 42-48.

Santos, X., Poquet, J.M., 2010. Ecological succession and habitat attributes affect the post-fire response of a Mediterranean reptile community. Eur. J. Wildl. Res. 56, 895-905.

Sasaki, K., Sasaki, Y., Fox, S., 2010. Endangered traditional beliefs in Japan: influences on snake conservation. Herpetol. Conserv. Biol. 5, 474-485.

Schuyler, P.T., Garcelon, D.K., Escover, S., 2002. Eradication of feral pigs (Sus scrofa) on Santa Catalina Island, California, USA. In: Veitch, C.R., Clout, M.N. (Eds.), Turning the Tide: The Eradication of Invasive Species. IUCN SSC Invasive Species Specialist Group, Gland, Switzerland and Cambridge, United Kingdom, pp. 274-286.

Seigel, R.A., 1993. Summary: future research on snakes or how to combat "lizard envy". In: Seigel, R.A., Collins, J.T. (Eds.), Snakes. Ecology and Behavior. Mc Graw Hill, New York, pp. 87-115.

Sun, L.X., Shine, R., Debi, Z., Zhengren, T., 2001. Biotic and abiotic influences on activity patterns of insular pit-vipers (Gloydius shedaoensis, Viperidae) from northeastern China. Biol. Conserv. 97 (3), 387-398.

Terribile, L.C., Olalla-Tárraga, M.Á., Morales-Castilla, I., Rueda, M., Vidanes, R.M., Rodríguez, M.Á., Diniz-Filho, J.A.F., 2009. Global richness patterns of venomous snakes reveal contrasting influences of ecology and history in two different clades. Oecologia 159, 617-626.

Tolley, K.A., Alexander, G.J., Branch, W.R., Bowles, P., Maritz, B., 2016. Conservation Status and Threats for African Reptiles (in this issue).

Tóth, T., Krecsák, L., Gál, J., 2010. Collecting and killing of the common adder (Vipera berus) in Hungary between 1950-1970. Northwest. J. Zool. 6, 79-85. 
Tuniev, B., Tuniev, S., 2009. Conservation strategy for endemic species of caucasian vipers (Pelias kaznakovi, P. dinniki). In: Zazanashvili, N., Mallon, D. (Eds.), Status and Protection of Globally Threatened Species in the Caucasus. CEPF, WWF. Contour Ltd., Tbilisi, pp. 165-170.

Uetz, P., Hošek, J. (Eds.), 2015. The Reptile Database (http://www.reptile-database.org/ accessed October 30, 2015).

Újvári, B., Korsós, Z., Péchy, T., 2000. Life-history, population characteristics and conservation of the Hungarian meadow viper (Vipera ursinii rakosiensis). Amphibia-Reptilia 21, 267-278.

Újvári, B., Madsen, T., Kotenko, T., Olsson, M., Shine, R., 2002. Low genetic diversity threatens imminent extinction for the Hungarian meadow viper (Vipera ursinii rakosiensis). Biol. Conserv. 105, 127-130.

Ursenbacher, S., Monney, J.-C., Fumagalli, L., 2008. Limited genetic diversity and high differentiation among the remnant adder (Vipera berus) populations in the Swiss and French Jura Mountains. Conserv. Genet. 10, 303-315.

Völkl, W., Thiesmeier, B., 2002. Die Kreuzotter. Laurenti Verlag, Bielefeld, p. 159.

Waldron, J.L., Bennett, S.H., Welch, S.M., Dorcas, M.E., Lanham, J.D., Kalinowsky, W., 2006. Habitat specificity and home-range size as attributes of species vulnerability to extinction: a case study using sympatric rattlesnakes. Anim. Conserv. 9, 414-420.

Watari, Y., Nishijima, S., Fukasawa, M., Yamada, F., Abe, S., Miyashita, T., 2013. Evaluating the "recovery level" of endangered species without prior information before alien invasion. Ecol. Evol. 3, 4711-4721.

WCS - Wildlife Conservation Society, CIESIN - Center for International Earth Science Information Network - Columbia University, 2005r. Last of the Wild Project, Version 2, 2005 (LWP-2): Global Human Influence Index (HII) Dataset (Geographic). NASA Socioeconomic Data and Applications Center (SEDAC), Palisades, NY (http://dx.doi. org/10.7927/H4BPooQC. Accessed: July 2015).

Weatherhead, P.J., Madsen, T., 2009. Linking behavioral ecology to conservation objectives. In: Mullin, S.J., Seigel, R.A. (Eds.), Snakes: Ecology and Conservation. Cornell University Press, Ithaca, New York, pp. 149-171.

Webb, J.K., Brook, B.W., Shine, R., 2002. What makes a species vulnerable to extinction? Comparative life-history traits of two sympatric snakes. Ecol. Res. 17, 59-67.

Weyer, J., Jørgensen, D., Schmitt, T., Maxwell, T.J., Anderson, C.D., 2014. Lack of detectable genetic differentiation between den populations of the prairie rattlesnake (Crotalus viridis) in a fragmented landscape. Can. J. Zool. 92, 837-846.

Young, B.A., Blair, M., Zahn, K., Marvin, J., 2001. Mechanics of venom expulsion in Crotalus, with special reference to the role of the fang sheath. Anat. Rec. 264 (4), 415-426.

Zamudio, K.R., Greene, H.W., 1997. Phylogeography of the bushmaster (Lachesis muta, ations for neotropical biogeography, systematics, and conservation. Biol. J. Linn. Soc. $62,421-442$. 
http://repository.uwc.ac.za 